Vol.25, No.2, Desember 2019

ISSN (p): 1693-590x, ISSN (e): 2686-4711

DOI: $10.36309 /$ goi.v25i2.111

\title{
Rancang Bangun Sistem Keamanan Smart Door Lock Menggunakan E-KTP (Elektronik Kartu Tanda Penduduk) Dan Personal Identification Number Berbasis Arduino Mega R3
}

\author{
Wisnu Wendanto ${ }^{1}$, D Jayus Nor Salim ${ }^{2}$, Dhika Wahyu Trisna Putra ${ }^{3}$ \\ ${ }^{13}$ Program Studi Sistem Komputer, STMIK AUB, Surakarta, Indonesia \\ ${ }^{2}$ Program Studi Sistem Informasi, STMIK AUB, Surakarta, Indonesia \\ e-mail: ${ }^{* 1}$ wisnu.wendanto@stmik-aub.ac.id, ${ }^{2}$ djayus.nur@stmik-aub.ac.id, \\ 3diikka_w@outlook.com
}

\begin{abstract}
Abstrak
Existing house door security during conventional still uses door locks as keys and often cases of door burglary and theft occur and the majority of homeowners work so the lack of house supervision by the owner. So we need a more practical and efficient key and more security for door locks, from this problem the author has the idea to produce a safe and practical door safety device based on RFID by utilizing e-KTP as an RFID tag and Keypad as a PIN to secure the door of the house. This design uses an Arduino Mega R3 microcontroller. This tool consists of several main components, namely e-KTP, RFID reader, microcontroller, $4 \times 4$ Keypad, Relay, and Solenoid Door Lock. The e-KTP chip functions as a label of an object in which there is data about the object. RFID reader is used as a reader of information contained in e-KTP. The microcontroller as the main controller, $4 \times 4$ keypad as personal access number identification and solenoid door lock as the key. The test results can be concluded that the door security system uses e-KTP and this PIN is able to read the e-KTP ID with a maximum distance of $1 \mathrm{~cm}$ with the MFRC522 sensor RFID reader which has a frequency of $13.56 \mathrm{MHz}$ placed in plywood 1cm thick. The PIN runs well by entering the 6 digit pin code on the available keypad. As well as the Solenoid Door Lock as a door lock runs smoothly.
\end{abstract}

Kata kunci: Door Security Systems, e-ID cards, RFID, Solenoid, PIN Keypad

\section{PENDAHULUAN}

Perkembangan jaman, inovasi peralatan baru banyak diciptakan guna mempermudah aktivitas manusia. Hal inilah yang mendorong perkembangan teknologi banyak menghasilkan alat sebagai piranti untuk mempermudah kegiatan manusia. Teknologi di era modernisani memegang perang penting saat ini, dimana teknologi menjadi bagian penting dalam kehidupan sehari-hari. Seiring semakin perkembangan teknologi dan jaman, kriminalitas juga semakin tinggi menyebabkan sistem keamanan menjadi kebutuhan mutlak untuk diterapkan, guna melindungi asset dan privasi yang kita miliki.

Sistem keamanan rumah yang ada selama ini masih konvensional. Adanya kasus pembobolan pintu rumah dan pencurian yang terjadi di Perumahan Margo Asri Sragen ketika ditinggal pemilik rumah. Perumahan Margo Asri Sragen memiliki 11 gang masuk dan mayoritas pemilik rumah bekerja sehingga kurangnya pengawasan dilokasi ada tempat pos satpam tetapi tidak ada satpamnya untuk menjaga 24 jam di Perumahan Margo Asri Sragen. Adanya keterbatasan tersebut maka penggunaan sistem keamanan paling disorot adalah pintu, karena fungsi pintu sebagai jalur akses utama untuk keluar masuk. Dengan memanfaatkan teknologi yang sudah sampai mikrokontroler dan memanfaatkan e-KTP (Elektronik Kartu Tanda

Received November 11, 2019; Revised November 25, 2019; Accepted December 9, 2019 
Penduduk) dalam e-KTP terdapat chip yang tertanam dapat dibaca ID nya menggunakan teknologi modul RFID RC522 (Radio Frequency Identification). Dengan memaanfaatkan teknologi e-KTP sebagai akses utama membuka pintu karena merupakan kartu identitas diri selalu dibawa saat berpergian.

Dari penggunaan e-KTP yang termasuk dalam jenis kartu pintar (smart card) e-KTP diharapkan dapat memiliki keamanan lebih tinggi dibandingkan dengan pengunci pintu konvensional, karena penguncinya tidak memiliki engsel kunci yang terlihat dari depan pintu dan cara pengoprasiannya secara elektronik. PIN (Personal Identification Number) merupakan keamanan tingkat kedua selain menggunakan e-KTP karena memungkinkan orang agar tidak menyalahgunakan e-KTP untuk akses masuk masuk selain pemilik e-KTP tersebut dengan keamanan menggunakan PIN. Sistem keamanan alat ini terdiri beberapa komponen utama yaitu e-KTP, RFID reader, mikrokontroler, PIN dan solenoid door lock. Chip e-KTP berfungsi sebagai label suatu objek yang didalamnya terdapat data tentang objek tersebut. RFID reader digunakan sebagai alat pembaca informasi yang ada pada e-KTP. Mikrokontroler sebagai pengontrol utama, PIN sebagai hak akses personal identifikasi nomor serta solenoid door lock sebagai penguncinya.

\section{METODE PENELITIAN}

\subsection{Analisis Sistem}

Analisa dan perancangan sebuah alat sangatlah penting. Hal ini bertujuan agar alat yang diciptakan dapat bekerja secara optimal sesuai dengan harapan, selain itu juga untuk mengurangi kesalahan dalam proses perancangan serta untuk bahan pertimbangan apabila terjadi masalah setelah alat tercipta. Analisis yang di buat sering adanya kasus pembobolan pintu rumah dan pencurian yang terjadi dan mayoritas pemilik rumah bekerja sehingga kurangnya pengawasan rumah oleh pemiliknya. Untuk itu berdasarkan masalah tersebut adalah perlu dilakukan penanganan khusus, guna mencegah terjadi kejahatan dan ancaman pencurian dan perampokan rumah sehingga mengurangi terjadinya tindak kejahatan dan kerugian materi.

Dari analisa sistem diatas maka penulis mempunyai gagasan atau ide untuk merancang suatu rangkaian interface yang berjudul "Rancang Bangun Sistem Keamanan Smart Door Lock Menggunakan E-Ktp (Elektronik Kartu Tanda Penduduk) Dan Pin (Personal Identification Number) Berbasis Arduino Mega R3”.

\subsection{Diagram Blok}

Perancangan merupakan inti dari seluruh pembuatan penelitian ini. untuk memudahkan perancangan dan pembuatan alat, maka dibuat diagram blok dari sistem secara keseluruhan. Berikut adalah diagram blok dari Sistem Keamanan Smart Door Lock menggunakan e-KTP ( Elektronik Kartu Tanda Penduduk ) dan Personal Identification Number Berbabis Arduino Mega R3 pada gambar 1.

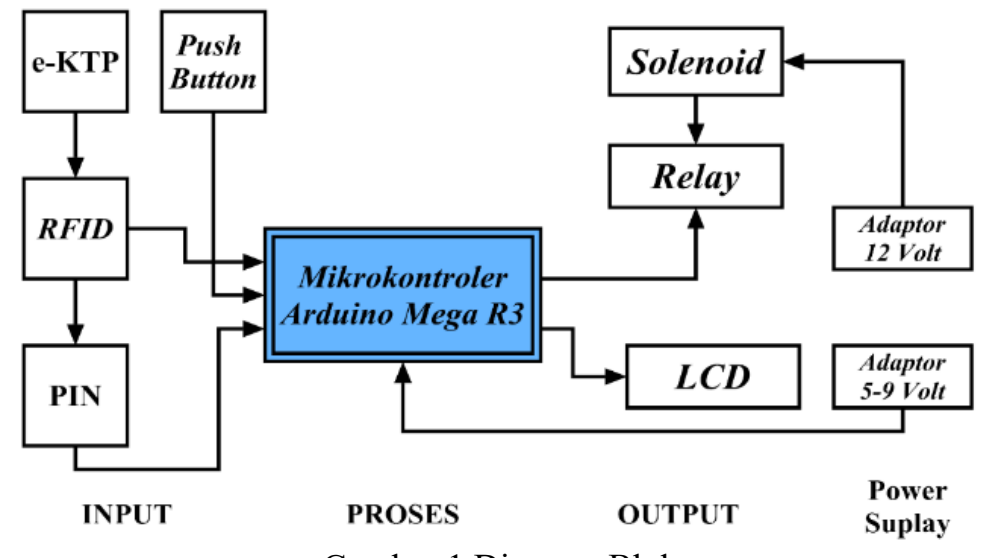

Gambar 1 Diagram Blok

GO INFOTECH: JURNAL ILMIAH STMIK AUB Vol. 25, No. 2, Desember 2019: 133-142 
Pada Diagram Blok perancangan alat gambar 1 memiliki sensor RFID reader yang berfungsi untuk membaca data ID dari e-KTP dan Keypad 4x4 Matriks sebagai Personal Identification Number. Mikrokontroler ATmega2560 berfungsi untuk mengakses data dari sensor RFID reader. LCD 16x2 berfungsi untuk menampilkan karakter sesuai program yang diberikan oleh mikrokontroler Atmega2560. Push button berfungsi untuk memberikan input logika high/low kepada mikrokontroler ATmega2560 untuk membuka pintu dari dalam rumah. Mikrokontroler berfungsi sebagai pusat kendali rangkaian yang akan mengaktifkan relay sehingga solenoid door lock aktif High dan kunci pintu dapat dibuka.

2.3 Flowchart Membuka Sistem Keamanan Pintu dari Depan

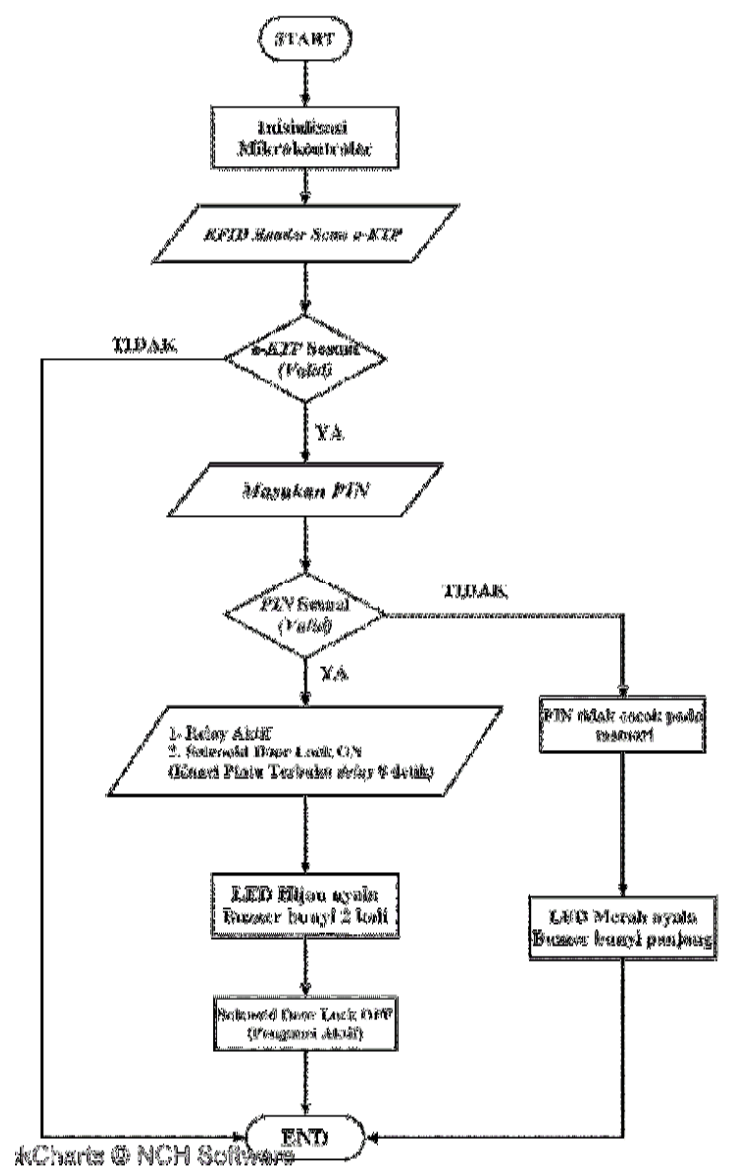

Gambar 2 Flowchart Sistem Keamanan Pintu Dengan e-KTP dan PIN

Penjelasan flowchart sistem keamanan pintu dengan e-KTP dan PIN pada gambar 2 dapat dijabarkan sebagai berikut :

1) START.

Langkah pertama untuk mengoperasikan alat yaitu dengan memberikan tegangan daya pada rangkaian alat.

2) Inisialisasi Mikrokontroler.

Setelah sistem aktif mikrokontroler Arduino Mega R3 akan melakukan fungsinya sebagai kontrol dari semua input dan output. Mikrokontroler Arduino Mega R3 mengaktifkan RFID reader dan LCD. Setelah aktif, LCD akan menampilkan tulisan untuk menempelkan e-KTP

3) RFID Reader Scan e-KTP.

RFID reader akan membaca data pada e-KTP melalui pancaran gelombang elektromagnetik. Data yang dibaca oleh RFID reader akan diteruskan ke mikrokontroler untuk divalidasi dengan memori mikrokontroler Arduino Mega R3.

4) e-KTP Sesuai atau Valid.

Rancang Bangun Sistem Keamanan Smart Door Lock Menggunakan E-KTP (Elektronik Kartu

Tanda Penduduk) Dan Personal Identification Number Berbasis Arduino Mega R3 (Wisnu) 
Apabila data yang dikirim oleh $R F I D$ reader bernilai valid (sesuai dengan memori) kapasitas memori mikrokontroler 128 byte akan menjalankan instruksi selanjutnya yaitu menunggu verifikasi PIN (Personal Identification Number).

5) PIN Sesuai atau Valid.

Apabila data yang dikirim oleh Keypad bernilai valid (sesuai dengan memori) kapasita memori mikrokontroler 128 byte akan menjalankan instruksi selanjutnya yaitu mengaktifkan relay dan solenoid door lock aktif high.

6) LED Hijau nyala dan Buzzer bunyi 2 kali.

LED hijau menyala dan buzzer akan berbunyi 2 kali, sebagai tanda bahwa e-KTP dan PIN berhasil verivikasi masuk.

7) Relay Aktif

Setelah data e-KTP dan PIN sesuai, mikrokontroler akan mengaktifkan relay untuk membuka pengunci pintu yaitu solenoid door lock aktif high maka pengunci akan terbuka, sehingga kunci pintu dapat dibuka selama 8 detik.

8) Solenoid Door Lock OFF.

Setelah 8 detik maka mikrokontroler Arduino Mega R3 akan memberikan intruksi kepada relay untuk aktif low dan solenoid door lock (off) pengunci akan tertutup.

9) PIN tidak cocok pada memori.

Apabila PIN tidak sesuai dengan database setelah verivikasi e-KTP maka proses berakhir dan kembali ke START.

10) LED Merah nyala dan Buzzer bunyi panjang.

LED merah menyala dan buzzer akan berbunyi panjang, sebagai tanda bahwa e-KTP dan PIN tidak berhasil verivikasi masuk.

11) END.

End disini adalah semua proses penguncian dan pembukaan akan kembali ke posisi inisialisasi mikrokontroler Arduino Mega R3 ( Looping ).

2.4 Flowchart Membuka Sistem Keamanan Pintu dari Dalam

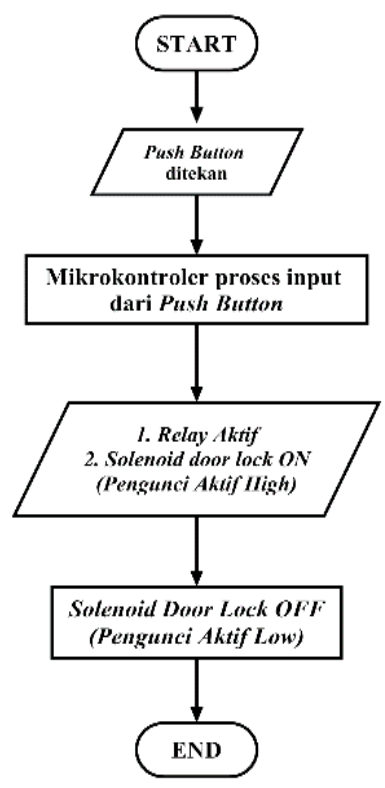

Gambar 3 Flowchart Sistem Keamanan Pintu dengan Push Button

Penjelasan flowchart sistem keamanan pintu dengan Push Button pada gambar 3 dapat dijabarkan sebagai berikut :

1) START.

Langkah pertama untuk mengoperasikan alat yaitu dengan memberikan tegangan daya pada rangkaian alat.

2) Push button ditekan.

GO INFOTECH: JURNAL ILMIAH STMIK AUB Vol. 25, No. 2, Desember 2019: 133-142 
Ketika membuka pintu dari dalam rumah dilakukan dengan menekan tombol push button.

3) Mikrokontroler memproses input dari Push Button.

Setelah push button ditekan, maka mikrokontroler akan memproses sesuai dengan program yang telah diberikan yaitu untuk mengaktifkan relay.

4) Relay Aktif.

Relay akan aktif setelah push button ditekan dan diproses oleh mikrokontroler.

5) Solenoid Door Lock ON.

Ketika relay aktif maka solenoid door lock aktif yaitu membuka kunci pintu, Setelah solenoid door lock aktif maka pengunci terbuka, sehingga kunci pintu dapat dibuka menekan tombol Push Button.

6) Solenoid Door Lock OFF.

Setelah tidak menekan tombol Push Button maka relay aktif low dan solenoid door lock (off) pengunci akan tertutup.

7) END.

END proses pembukaan pintu rumah menggunakan push button telah selesai.

\section{HASIL DAN PEMBAHASAN}

\subsection{Hasil dan Pengujian}

Proses pengujian ini dilakukan dengan mencoba membaca data yang ada dalam e-KTP dengan modul RFID Reader apakah terdapat data yang diperlukan untuk proses penelitian berjalan dengan baik terlihat pada gambar 4 proses pengujian RFID Reader.

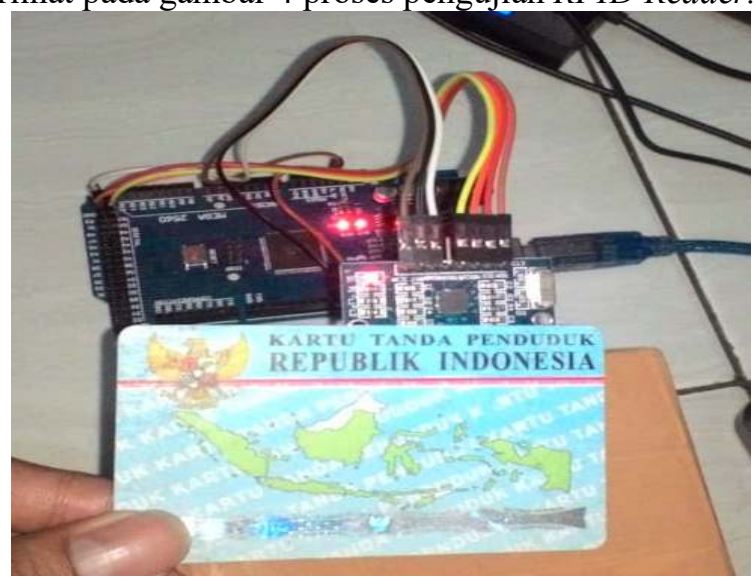

Gambar 4 Pengujian RFID dengan e-KTP

Untuk dapat mengambil data dari pengujian RFID Reader maka keterangan untuk setiap port pin RFID Reader terhubung ke Arduino Mega R3 dijelaskan ditabel 1.

Tabel 1 Port RFID Reader dengan Arduino Mega R3

\begin{tabular}{|c|c|}
\hline Modul RC522 & PIN ARDUINO MEGA \\
\hline SDA & D9 \\
\hline SCK & D52 \\
\hline MOSI & D51 \\
\hline MISO & D50 \\
\hline IRQ & Tidak Ada \\
\hline GND & GND \\
\hline RST & D8 \\
\hline $3.3 \mathrm{~V}$ & $3.3 \mathrm{~V}$ \\
\hline
\end{tabular}

Rancang Bangun Sistem Keamanan Smart Door Lock Menggunakan E-KTP (Elektronik Kartu Tanda Penduduk) Dan Personal Identification Number Berbasis Arduino Mega R3 (Wisnu) 
Setelah proses pengujian dengan menempelkan e-KTP terdapat data muncul diserial monitor arduino IDE yang berguna sebagai verifikasi nanti. Terlihat pada gambar nomor 4.2 data yang diambil dari e-KTP.

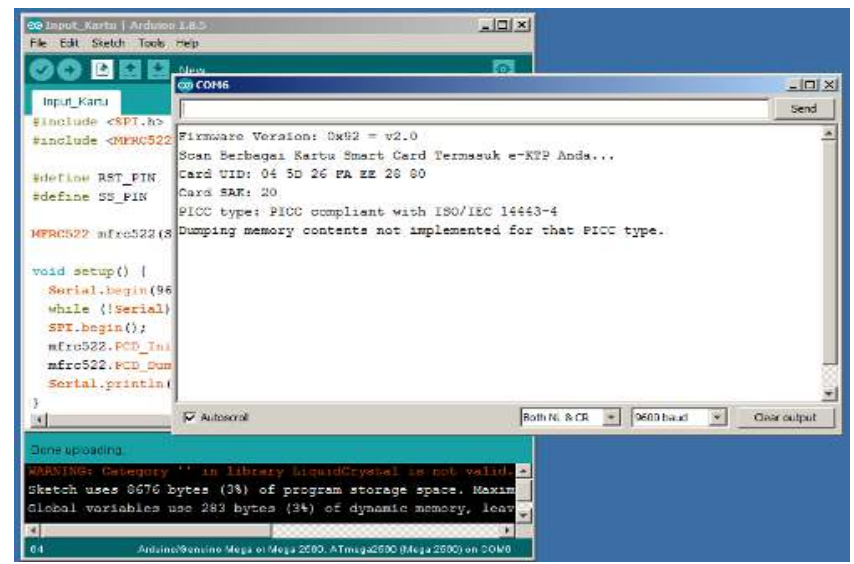

Gambar 5 Pengujian RFID dengan e-KTP kode UID

Terlihat pada gambar 5 Card UID: 04 5D 26 FA EE 2880 adalah data yang bisa digunakan untuk verifikasi dalam pembuatan sistem keamanan pintu ini. Tabel 2 menunjukan hasil pembacaan beberapa kartu.

Tabel 2 Hasil Pembacaan RFID Tag ke RFID Reader.

\begin{tabular}{|c|c|c|c|}
\hline \multirow{2}{*}{$\begin{array}{l}\text { Tipe } \\
\text { Kartu } \\
\text { RFID Tag }\end{array}$} & \multicolumn{3}{|c|}{$\begin{array}{l}\text { Hasil Identifikasi } \text { Kartu } \\
\text { Reader }\end{array}$} \\
\hline & No & Card UID & Card SAK \\
\hline \multirow{2}{*}{$e-K T P$} & 1 & $\begin{array}{lll}04 & 5 D & 26 \\
F A & E E & 28 \\
80 & & \end{array}$ & 20 \\
\hline & 2 & $\begin{array}{ccc}04 & 7 C & 6 B \\
22 & E 4 & 5 C \\
80 & & \end{array}$ & 20 \\
\hline \multirow{2}{*}{$\begin{array}{l}\text { RFID } \\
\text { Tag }\end{array}$} & 1 & $\begin{array}{ccc}A 0 & A 1 & 65 \\
03 & & \end{array}$ & 08 \\
\hline & 2 & $\begin{array}{lll}F 0 & 50 & 6 C \\
03 & & \end{array}$ & 08 \\
\hline
\end{tabular}

Proses pengujian jarak pembacaan sensor RFID reader dengan e-KTP dilakukan menggunakan halangan dan RFID reader berada dalam Triplek dengan tebal $1 \mathrm{~cm}$. Pengukuran jarak e-KTP dengan $R F I D$ reader bertujuan untuk mengetahui jarak $R F I D$ reader dapat membaca ID pada e-KTP. Terlihat pada tabel 2 data pengujian jarak RFID Reader.

Tabel 2 Pengambilan Data Jarak E-KTP Dengan RFID Reader

\begin{tabular}{|c|c|c|c|}
\hline No & Tipe Tag ID & Jarak $(\mathrm{cm})$ & Keterangan \\
\hline 1 & \multirow{8}{*}{ e-KTP } & $0 \mathrm{~cm}$ & Terbaca \\
\hline 2 & & $0,2 \mathrm{~cm}$ & Terbaca \\
\hline 3 & & $0,4 \mathrm{~cm}$ & Terbaca \\
\hline 4 & & $0,6 \mathrm{~cm}$ & Terbaca \\
\hline 5 & & $0,8 \mathrm{~cm}$ & Terbaca \\
\hline 6 & & $1 \mathrm{~cm}$ & Terbaca \\
\hline 7 & & $1.2 \mathrm{~cm}$ & $\begin{array}{l}\text { Tidak } \\
\text { Terbaca }\end{array}$ \\
\hline 8 & & $1.4 \mathrm{~cm}$ & $\begin{array}{l}\text { Tidak } \\
\text { Terbaca }\end{array}$ \\
\hline
\end{tabular}

Pengujian LCD bertujuan untuk memastikan LCD L2C berfungsi sesuai dengan apa yang sudah diperintahkan oleh program. Dalam hasil pengujian membuktikan tampilan pada LCD yang sudah diprogram sebagai output. Berikut tampilan awal sistem keamanan pintu dalam pengujian LCD L2C terlihat pada tabel 3. 
Tabel 3 Pengujian LCD L2C

\begin{tabular}{|c|c|c|}
\hline No. & Karakter yang ditampilkan LCD & Keterangan \\
\hline 1 & Selangt Dglad & Tampilan awal \\
\hline 2 & 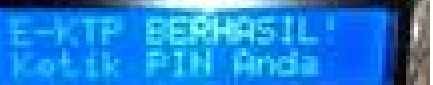 & $\begin{array}{l}\text { Tampilan setelah berhasil verifikasi } \\
\text { e-KTP }\end{array}$ \\
\hline 3 & 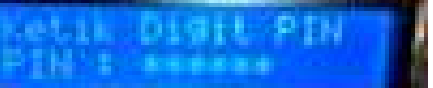 & Tampilan setelah mengetikan PIN \\
\hline 4 & 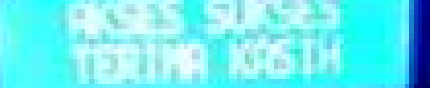 & $\begin{array}{l}\text { Tampilan setelah sukses verifikasi } \\
\text { PIN }\end{array}$ \\
\hline
\end{tabular}

Proses pengujian ini dilakukan dengan mencoba keypad yg memiliki 16 digit tombol yang terdiri dari 10 angka 2 karakter (* dan \#) 4 huruf ( A B C ) dengan menampilkan keterangan di LCD. Berikut gambar 6

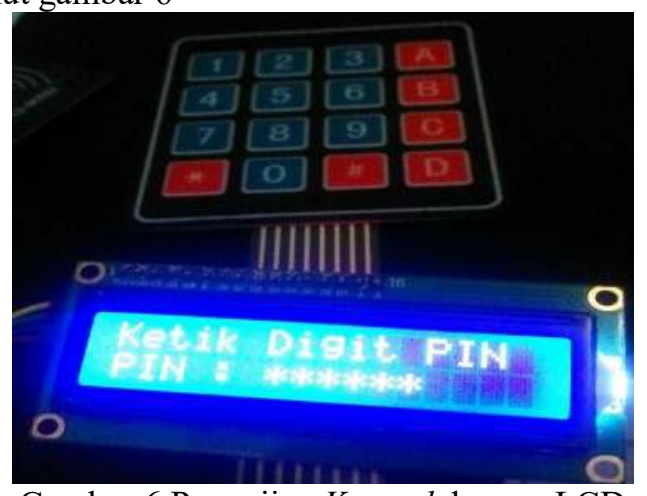

Gambar 6 Pengujian Keypad dengan LCD

Proses memasukkan PIN dengan cara menekan tombol keypad. Format tombol yang digunakan adalah format angka. Dengan menekan tombol angka untuk menentukan PIN. Proses menekan PIN setelah verifikasi e-KTP. Berikut tabel 4 Pengujian Keypad 4x4.

Tabel 4 Pengujian Keypad 4x4

\begin{tabular}{|l|c|c|c|c|}
\hline No & $\begin{array}{c}\text { Membran } \\
\text { Keypad 4x4 }\end{array}$ & Input & Hasil & Keterangan \\
\hline 1 & Tombol 1 & Ditekan & Aktif & Berfungsi \\
\hline 2 & Tombol 2 & Ditekan & Aktif & Berfungsi \\
\hline 3 & Tombol 3 & Ditekan & Aktif & Berfungsi \\
\hline 4 & Tombol 4 & Ditekan & Aktif & Berfungsi \\
\hline 5 & Tombol 5 & Ditekan & Aktif & Berfungsi \\
\hline 6 & Tombol 6 & Ditekan & Aktif & Berfungsi \\
\hline 7 & Tombol 7 & Ditekan & Aktif & Berfungsi \\
\hline 8 & Tombol 8 & Ditekan & Aktif & Berfungsi \\
\hline 9 & Tombol 9 & Ditekan & Aktif & Berfungsi \\
\hline 10 & Tombol 0 & Ditekan & Aktif & Berfungsi \\
\hline 11 & Tombol \# & Ditekan & Aktif & Berfungsi \\
\hline 12 & Tombol * & Ditekan & Aktif & Berfungsi \\
\hline 13 & Tombol A & Ditekan & Tidak Aktif & Tidak Berfungsi \\
\hline
\end{tabular}

Rancang Bangun Sistem Keamanan Smart Door Lock Menggunakan E-KTP (Elektronik Kartu Tanda Penduduk) Dan Personal Identification Number Berbasis Arduino Mega R3 (Wisnu) 


\begin{tabular}{|l|l|l|l|l|}
\hline 14 & Tombol B & Ditekan & Tidak Aktif & Tidak Berfungsi \\
\hline 15 & Tombol C & Ditekan & Tidak Aktif & Tidak Berfungsi \\
\hline 16 & Tombol D & Ditekan & Tidak Aktif & Tidak Berfungsi \\
\hline
\end{tabular}

Relay berfungsi untuk mengendalikan solenoid, relay digunakan sebagai saklar untuk mengaktifkan solenoid. Pengukuran tegangan input relay pada rangkaian adalah 12 Volt DC. Pada alat sistem keamanan pintu relay dikendalikan oleh mikrokontroler sebagai saklar untuk mengaktifkan solenoid. Berikut gambar 7 menampilkan Relay menyala dengan kondisi Aktif Low.

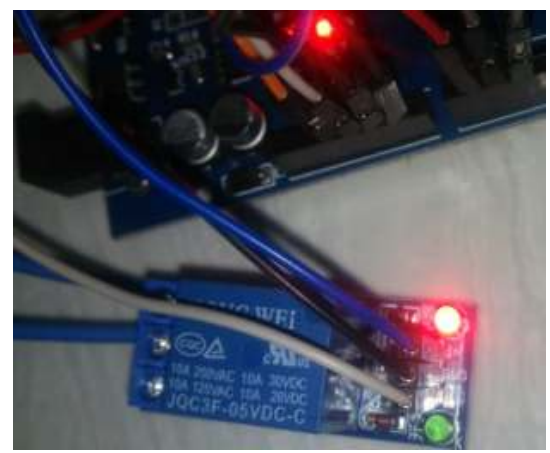

Gambar 7 Pengujian Relay

Dalam pengujian Relay dengan solenoid terdapat data pengujian yang dapat dijelaskan pada tabel 5 berikut:

Tabel 5 Pengujian Solenoid Door Lock

\begin{tabular}{|c|c|c|c|c|c|}
\hline No & Modul Komponen & Input Aksi & $\begin{array}{c}\text { Kondisi } \\
\text { Awal }\end{array}$ & Hasil & Keterangan \\
\hline 1 & Relay & $\begin{array}{c}\text { Tidak Ada } \\
\text { Input }\end{array}$ & $\begin{array}{c}\text { Aktif Nyala } \\
\text { Merah }\end{array}$ & $\begin{array}{c}\text { Aktif Low } \\
\text { (Tidak } \\
\text { Ada Aksi) }\end{array}$ & $\begin{array}{c}\text { Kondisi ini relay tidak } \\
\text { memberikan arus daya }\end{array}$ \\
\hline 2 & Relay & Ada Input & $\begin{array}{c}\text { Aktif Nyala } \\
\text { Hijau }\end{array}$ & Aktif High & $\begin{array}{c}\text { Kondisi ini relay tidak } \\
\text { menghantarkan arus daya }\end{array}$ \\
\hline
\end{tabular}

Dari tabel 5 di atas dapat dilihat bahwa untuk membuka kunci solenoid maka masukan daya 12 Volt diberikan logika 1 (High). Hal tersebut dikarenakan oleh relay yang digunakan yaitu normali close (NC). Sehingga saklar akan terhubung dengan Adaptor 12 Volt.

Pengujian Push button disini digunakan untuk memberi tegangan pada solenoid sebesar $12 \mathrm{~V}$, dimana fungsinya untuk melakukan ON dan OFF terhadap kerja solenoid yang dihubungkan pada mikrokontroller. Saat posisi tombol ditekan maka akan diberikan tegangan High (1) Ketika tidak ada penekanan tombol, maka dalam kondisi Low (0) dan tidak ada tegangan. Terlihat pada gambar 8 pengujian push button.

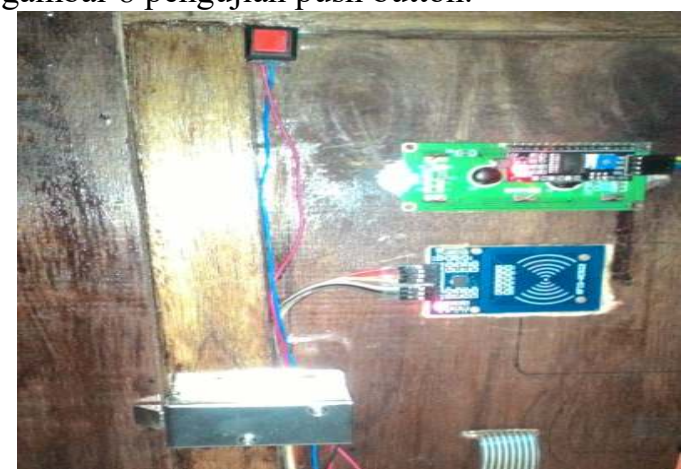

\subsection{Pembahasan}

Gambar 8 Pengujian Push Button

Dalam rancang bangun sistem keamanan pinti ini menggunakan e-KTP sebagai RFID tag, berdasarkan wikipedia indonesia bentuk KTP elektronik sesuai dengan ISO 7810 dengan 
format seukuran kartu kredit yaitu 53,98 mmx85,60 mm. Penyimpanan data di dalam chip sesuai dengan standar internasional NISTR 7123 dan Machine Readable Travel Documents ICAO 9303 serta EU passport specification 2006. Berdasarkan buku panduan ISO/IEC 7810:2003 kartu dengan standar ISO/ICE 7810 merupakan kartu identifikasi yang termasuk dalam golongan smart card sama dengan kartu dengan standar ISO/IEC 14443 yang dapat digunakan sebagai identification card. Dari beberapa artikel dan jurnal tersebut dapat disimpulkan bahwa e-KTP dapat digunakan sebagai RFID tag dengan frekuensi 13.56 yang termasuk dalam RFID tag jenis HF (High Frekuensi).

Pada hasil proses pengujian RFID reader MFRC 522 pada rancang bangun sistem keamanan pintu menggunakan e-KTP yang diletakkan didalam triplek dengan ketebalan $1 \mathrm{~cm}$ dapat membaca e-KTP dengan jarak maksimal $1 \mathrm{~cm}$. Setelah dilakukan pengujian, Keypad dapat menjadi verikasi keamanan kedua setelah e-KTP dan solenoid door lock dapat menjadi pengunci pintu rumah ketika e-KTP yang didekatkan atau ditempelkan dapat dibaca RFID reader dan nomor ID dapat diakses oleh mikrokontroler yaitu pada jarak maksimal $1 \mathrm{~cm}$.

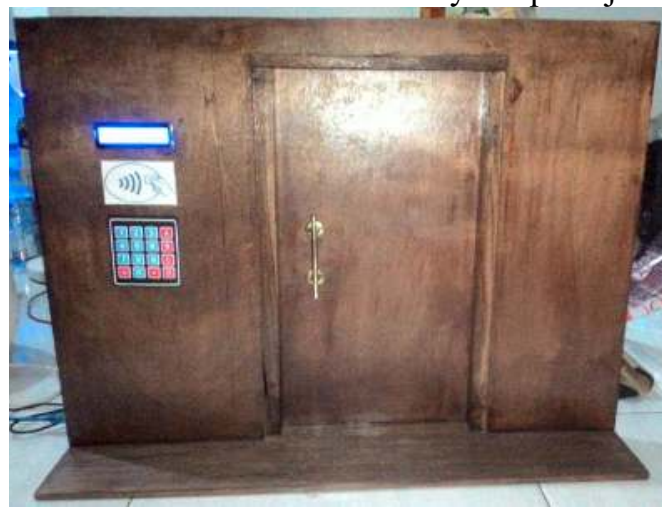

Gambar 9 Sistem Keamanan Pintu dari Depan

Pada gambar 9 menjelaskan cara penggunaan alat sistem keamanan pintu dari depan pintu pertama kali adalah dengan menempelkan e-KTP yang sudah terdaftar di pintu bagian yang sudah disediakan RFID Reader dibagian bawah layar LCD dan diatas Keypad. Bila verifikasi e-KTP berhasil maka lanjut verifikasi ketik PIN, verifikasi e-KTP berlangsung selama 8 detik setelah e-KTP berhasil terbaca, bila lebih dari 8 detik Led Merah nyala dan Buzzer akan berbunyi panjang. Setelah berhasil verifikasi e-KTP berlanjut mengetikan PIN pada Keypad, bila berhasil verikasi Keypad maka Solenoid aktif high yaitu membuka kunci pintu dengan delay 8 detik bersama dengan LED hijau nyala Buzzer bunyi 2 kali kemudian mendorong gagang pintu kedalam untuk masuk kedalam rumah, bila kode PIN salah LED merah nyala dan Buzzer bunyi panjang akan kembali keawal untuk verifikasi e-KTP kembali. Gambar 10 menjelaskan tentang cara kerja sistem keamanan pintu dari dalam menggunakan Push Button.

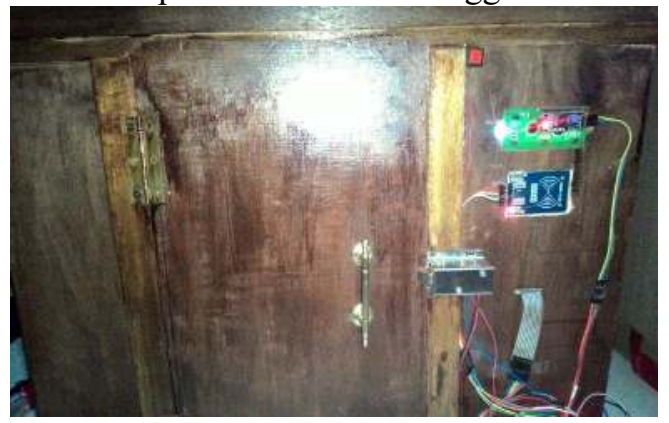

Gambar 10 Sistem Keamanan Pintu dari Dalam

Untuk membuka pintu dari dalam rumah cukup dengan menekan tombol Push Button yang terdapat dibagian Kusen Pintu maka solenoid akan aktif high sehingga kunci pintu membuka.

Rancang Bangun Sistem Keamanan Smart Door Lock Menggunakan E-KTP (Elektronik Kartu Tanda Penduduk) Dan Personal Identification Number Berbasis Arduino Mega R3 (Wisnu) 


\section{KESIMPULAN}

Telah dirancang dan dibangun Sistem Keamanan Smart Door Lock Menggunakan EKTP Dan PIN Berbasis Arduino Mega R3. Dalam pemrograman menggunakan Arduino IDE v1.8.5 dengan bahasa pemrograman bahasa C. Komponen Solenoid 12 volt sebagai pengunci pintu. Komponen RFID sebagai pembaca e-KTP dan Smart Card. Komponen Keypad 4x4 sebagai kode PIN. Komponen LCD L2C menampilkan keterangan. Komponen Push Button sebagai pembuka kunci pintu dari dalam rumah. Komponen Relay sebagai saklar solenoid. Sistem keamanan pintu menggunakan e-KTP dan PIN dapat dibuat dan dioperasikan dengan mikrokontroler Arduino Mega R3 sebagai pusat kendali rangkaian dan diprogram menggunakan software IDE Arduino. Sistem keamanan pintu menggunakan e-KTP ini mampu membaca ID eKTP dengan jarak maksimal $1 \mathrm{~cm}$ dengan sensor RFID reader MFRC522 yang memiliki frekuensi 13.56 MHz diletakkan dalam Triplek dengan tebal $1 \mathrm{~cm}$.

\section{SARAN}

Sistem keamanan pintu dapat dikembangkan dengan ditambahkan Motor Stepper, sehingga pintu dapat membuka dan menutup secara otomatis setelah kunci pintu terbuka. Sistem keaamanan pintu dapat dikembangkan dengan menambah sensor keamanan lagi seperti sensor sidik jari sebagai pengganti Personal Identification Number. Penambahan RFID Tag tidak harus lewat laptop dan hanya dengan RFID Tag Master bisa menambahkan anggota baru.

\section{DAFTAR PUSTAKA}

[1] Djuandi, Feri. 2011. Pengenalan Arduino. www.tobuku.com. diakses pada hari jum'at tangga 11 Mei 2018.

[2] Guntoro, Helmi, dkk. 2013. Rancang Bangun Magnetic Door Lock Menggunakan Keypad Dan Solenoid Berbasis Mikrokontroler Arduino Uno. Bandung: Universitas Pendidikan Indonesia.

[3] Kurnianto, dkk. 2017. Penerapan Kartu Elektronis Berbasis Near Field Communication (NFC) Pada System Keamanan Pintu Rumah Cerdas. http://ejournal.st3telkom.ac.id/index.php/infote. diakses pada hari rabu tanggal 08 Mei 2018.

[4] Kartu Tanda Penduduk elektronik. (2018, April 19). Di Wikipedia, Ensiklopedia Bebas. Diakses pada hari jum'at tanggal 11 Mei 2018, dari https://id.wikipedia.org/w/index.php?title=Kartu_Tanda_Penduduk_elektronik\&oldid=13 844390.

[5] Muhamad Saleh. 2017. Rancang Bangun Sistem Keamanan Rumah Menggunakan Relay. Jakarta: Universitas Suryadarma.

[6] Pratama. 2011. Perancangan Perangkat System Pengendali Keamanan Pintu Rumah Berbasis Pesan Singkat (SMS) Menggunakan Mikrokontroler Atmega8535. Semarang: Universitas Diponegoro.

[7] Surasa, Hendra. 2017. Sistem Kunci Otomatis menggunakan Teknologi RFID Bebasis Mikrokontroler. Makassar: STMIK Kharisma.

[8] Saputro, Wibawanto. 2016. Rancang Bangun Pengaman Pintu Otomatis Menggunakan eKTP Berbasis Mikrokontroler Atmega328. Semarang: Universitas Negeri Semarang.

[9] Santoso, dkk. 2015. Perancangan Perangkat System Pengendalian Keamanan Pintu Rumah Berbasis Pesan Singkat (Sms) Menggunakan Mikrokontroler Atmega 8535. https://www.researchgate.net/publication/279465904. diakses pada hari jum'at tanggal 11 Mei 2018

GO INFOTECH: JURNAL ILMIAH STMIK AUB Vol. 25, No. 2, Desember 2019: 133-142 